\title{
Kebijakan Omnibus Law Dalam Perspektif Kebijakan Buruh Di Indonesia
}

\author{
Yusril Rahman Hakim ${ }^{1}$
}

Diserahkan: 22 Januari 2021 | Diterima: 13 Desember 2021 | Diterbitkan: 16 Desember 2021

\section{Abstrak}

Dalam penyelenggaraan pemerintahan di suatu negara diperlukan adanya aturan atau regulasi untuk mengatur masyarakatnya agar menjadi lebih teratur dan tertib. Regulasi atau aturan yang dimaksud adalah bagaimna kebijakan yang dibuat oleh pemerintah, baik itu undang-undang, PP dan sebagainya mampu menyelesaikan permasalahan yang ada di masyarakat. Dalam pengimplemntasiannya kebijakan publik melewati beberapa tahapan sebelum benar benar di realisasikan salah satunya tahap formulasi. Permasalahannya adalah ketika suatu kebijakan yang diformulasikan masih pada tahap formulasi hanya berpihak pada beberapa oknum, tanpa melihat impact dari kebijakan itu yang berdampak pada masyarakat kecil seperti buruh atau pekerja contohnya Omnibus Law RUU Cipta Lapangan Kerja. Yang mana seharusnya kebijakan yang dibuat ditujukan untuk menyelesaikan masalah malah sebaliknya, hadirnya omnibuslaw malah menjadi momok buruk bagi para buruh dan pekerja lainya. Metode yang digunakan pada penulisan ini adalah metode literatur review dengan menggunakan analisis kebijakan Van Horn \& Van Metter. Hasil serta temuan penelitian ini menemukan titik terang yaitu dimana omnibuslaw secara spesifik hanya menguntungkan pihak investor atau corporation dan melupakan pemenuhan hak hak terhadap buruh salah satunya penurunan UMK serta Pemutusan kerja tanpa tuntutan dsb.

Kata kunci : Kebijakan Publik, Omnibus Law, Pemerintah, dan Buruh

1 Mahasiswa Program Studi Ilmu Pemerintahan Universitas Muhammadiyah Malang. 
Rivaldi Mahardika 


\section{PENDAHULUAN}

Kebijakan publik merupakan salah satu hasil output dari proses penyelenggaraan pemerintahan, secara substansi kebijakan publik akan selalu berkaitan dengan berbagai aspek keberadaan pemerintahan terutama negara, pemerintah dan juga masyarakat yang menerima dampak dari kebijakan yang dibuat oleh pemerintah tersebut. kebijakan publik merupakan output yang dihasilkan oleh hasil kinerja pemerintah dalam mengimplementasikan tugas dan fungsi sebagai penggerak roda pemerintahan. Dengan begitu ketika proses decision making, pemerintah juga harus memperhatikan kondisi masyarakat terlebih dahulu karena kehidupan masyarakat bersifat dinamis, dengan demikian hasil dari kebijakan tersebut dapat menjawab problematika yang terjadi di masyarakat.

Ada beberapa tahapan dalam pelaksanaan kebijakan publik yakni formulasi, implementasi dan evaluasi. Sebelum pada tahapan implementasi dan evaluasi, kebijakan berada pada tahap perumusan kebijakan atau formulasi kebijakan yang melibatkan aktoraktor tertentu, dengan tujuan agar nantinya kebijakan tersebut sesuai dengan sasaran dan mampu menjawab problemaika yang terjadi di masyarakat, dengan 
demikian tahap formulasi ini merupakan tahapan yang penting dalam pembentukan suatu kebijakan publik.

Artikel ini mendiskusikan bagaiamana adanya permasalahan dalam tahap formulasi kebijakan publik, contohnya seperti permasalahan yang sedang hangat untuk diperbincangkan adalah RUU Omnibus Law, UU No. 11 tahun 2020 tentang Cipta Kerja. Dalam bahasa latin omnibus law diartikan sebagai hukum untuk semuanya. Maksudnya omnibus law ini hadir untuk menggabungkan beberapa undang-undang yang ada menjadi satu kesatuan undang-undang yang ditujukan untuk satu kepentingan bersama, menurut Osgar Sahim Matompo, omnibus law ini di tujukan untuk menggabungkan kebijakan yang di buat oleh pemerintah pusat atau pemerintah daerah untuk meningkatkan angka investasi negara dan juga memberikan jaminan perlindungan hukum bagi pembuat kebijakan, yang artinya tujuan omnibus law ini adalah untuk menguatkan jaringan para investor agar dapat meningkatkan daya saing ekonomi sekala global (Osgar Sahim Matompo, 2020). Singkatnya, omnibus law memang tidak mendapatkan tanggapan yang serius dikarenakan tidak punya payung hukum yang menyelimuti dalam implementasiannya dikarenakan masih berpacu pada hukum Eropa Kontinental. Overlapping regulasi yang 
sering dialami di Indonesia yang menjadi alasan omnibus law di populerkan kembali pada masa ini (Osgar Sahim Matompo,2020). Ima Mayasari (2020) juga menyatakan ketidakpastian hukum serta undang-undang yang kerap tumpang tindih yang menjadikan omnibus law ini sebagai sarana menyelesaikan permasalahan tersebut.

Berbeda halnya dengan omnibus law Cipta Lapangan Kerja yang mana seharusnya aturan dibuat untuk menyelesaikan problematika yang ada, ini malah sebaliknya, adanya UU Cipta Lapangan Kerja ini menimbulkan kotradiksi buruh terhadap pemerintah dalam pemenuhan hak-hak buruh. Menurut Achmad Nurcholis dalam Kendari Pos (2020), isu yang diangkat oleh buruh adalah terkait penghapusan upah minimum kerja, pesangon dan penghapusan pidana bagi pengusaha yang melanggar aturan hukum beberapa seperti halnya, jam kerja yang tidak normal dan hak libur pekerja bagi pekerja perempuan. Adapun beberapa UU yang dianggap dilanggar oleh Omnibus Law antara lain UU No. 23 tahun 2014 tentang Pemerintah Daerah, PP No. 24 tahun 2018 Tentang Perizinan, UU No. 21 tahun 2000 tentang Organisasi Serikat, Federasi, Konfederasi, UU No. 13 tahun 2003 tentang Ketenagakerjaan, Mengatur Jam Kerja dan UU No. 2 tahun 2004 tentang 
Permasalahan Kerja dan Mengantisipasi Adanya PHK dan Juga Penetapan upah.

Dari pemaparan diatas, tulisan ini mengambil rumusan masalah sebagai berikut: Mengapa omnibus law mengalami penolakan oleh buruh di indonesia? Tujuan daripada pengambilan rumusan masalah tersebut adalah untuk mengetahui apa yang sebenarnya menjadi problematika omnibus law terhadap kesejahteraan pekerja maupun buruh di Indonesia sehingga terjadi penolakan atas keberadaan omnibus law.

\section{SISTEM DAN PRAKTIK OMNIBUS LAW DI BERBAGAI NEGARA}

Omnibus pertama kali dikenalkan di inggris pada tahun 1861 mengatur tentang perjanjian perkeretaapian di Inggris. Menurut Lorne Gunther, Inggris menggunakan metode omnibus sejak tahun 1860 dalam penyusuanan undang-undang salah satunya yaitu Budget Finance Bill, yang merupakan omnibus tertua yang ada di Inggris. Seiring berjalannya waktu negara-negara lainya mulai menggunakan metode omnibus. Omnibus bill ini pertama kalinya diperkenalkan di Kanada pada tahun 1967 saat pengajuan amandemen hukum kriminal. Di negara Kanada omnibus adalah salah satu sarana dan 
juga metode parlemen dalam merancang, mengubah, mencabut, dan menggabungkan undang undang dengan tujuan untuk mempersingkat proses legislasi (Juwana, Gianova, \& Mega, 2020).

Amerika adalah negara kedua yang menggunakan omnibus sebagai sarana dalam mengatur undang undang negara, salah satunya adalah Omnibus Spending Bill, yang mana omnibus spending bill ini adalah aturan yang mengatur belanja negara dengan artian omnibus spending bill ini mengatur terkait anggaran belanja negara satu tahun kedepanya. Meski metode omnibus ini telah berjalan pada tahun 2018, Amerika mengalami goverment shutdown dikarenakan parlemen tidak mampu mengkaji omnibus spending bill dalam waktu yang singkat, yang mengakibakan pemerintah ditutup karena gagal dalam menyepakati anggaran yang digunakan dalam operasional pemerintah.

Jerman juga pernah menggunakan metode omnibus ini dalam pengaturan undang-undangnya. Mengutip dari Federal Ministry Of Justice Jerman ada beberapa kelebihan yang membat Jerman juga menggunakan metode omnibus ini, yang pertama terkait proses legislasi di parlemen akan lebih cepat, kedua biaya lebih hemat dalam penyusunan sampai pembahasan, dan 
memudahkan parlemen dalam memahami keterkaitan antar peraturan undang-undang.

Menurut Sofyan Djalil (Menteri Agraria dan Tata Ruang), konsep omnibus law sendiri di indonesia sebenarnya adalah untuk mencakup serta memperbaiki beberapa undang-undang yang tumpang tindih yang dapat menghambat proses berusaha. Maka dari itu harapanya kedepan, konsep omnibus law ini dapat mengatasi serta menemukan titik terang permasalahan tumbang tindih undang-undang serta undang-undang yang saling bertentangan (Kurniawan, \& Dewanto, 2020).

Ada beberapa faktor yang menjadi kelemahan omnibus law sehingga menimbulkan kontradiksi terhadap para buruh yang pertama yaitu perumusannya yang kurang terbuka dalam perumusanya serta tidak melibatkan seluruh elemen terutama dari elemen buruh. Menurut Alnick Nathan (2020) omnibus law yang dijunjung mampu menghasilkan lapangan pekerjaan justru malah menjadi hal yang tidak ingin diterima oleh para pekerja atau buruh, dikarenakan ketidakpastian serta perampasan hak-hak yang telah di tetapkan sebelumnya. Posisi seperti ini tidak hanya dirasakan pada sektor kota tapi juga sektor kabupaten seperti data yang di dapatkan Wulansari (2019) bagaimana 
peraturan pemerintah tentang upah minimum membuat nominal upah menjadi menurun yang mengakibatkan ketidaklayakan kehidupan buruh di setiap daerah karena ketidak cukupan memenuhi setandar kehidupan yang layak

Tidak hanya itu juga mirisnya UU Cipta Lapangan Kerja ini juga menghilangkan ketentuan terkait upah minimum kerja dan upah minimum sektoral, dan juga besaran upah yang di terima mngacu pada upah minimum provinsi yang diatur oleh gubernur yang mengakibatkan penurunan nominal upah minimum bagi pekerja atapun buruh di seluruh indonesia diakrenakan upah minimum pekerja lebih rendah dari upah miminum kerja (Nathan, 2020).

\section{KEBIJAKAN BURUH DARI 2015-2019 KONDISI BURUH SEBELUM TERBITNYA RUU OMNIBUS LAW DI INDONESIA}

Tujuan digunakannya metode omnibus law di indonesia tidak lain untuk menyelesaikan permasalahan yang sampai saat ini sering terjadi di indonesia yaitu, permasalahan tumpang tindih undang-undang yang ada. Maka dari itu, adanya omnibus law ini di harapkan mampu menjadi jalan keluar dalam mengatasi masalah 
tumpang tindih Undang-Undang tersebut. (Teguh Wahyudi, 2020).

Akan tetapi beberapa poin tujuan tersebut malah menimbulkan kontra terhadap hak-hak buruh yang mengakibatkan perdebatan yang tidak hanya terjadi pada saat terbitnya Rancangan Undang-Undang Omnibus Law Cipta Lapangan Kerja, tetapi juga pada tahap formulasi pada tahun 2015, jauh sebelum adanya RUU Omnibus Law (Retnowti, 2021). Pemerintah menerbitkan beberapa peraturan yang mampu mendegregrasi hakhak buruh dan berikut beberapa regulasi yang terbit dari tahun 2015-2019 (http://majalahsedane.org)

1. PP Nomor 41 tahun 2015 tentang Pembangunan Sumber Daya Industri, dimana dalam isi ketentuannya yaitu melegalkan praktik upah murah dengan mempekerjakan buruh atas dalih kerja magang dan mewajibkan perusahaan kawasan indutsri untuk mempekerjakan buruh dengan standar tertentu

2. PP Nomor 78 tahun 2015 tentang Pengupahan, yang menghilangkan peran dari serikat buruh dalam perundingan penentuan kenaikan upah minimum dan perhitungan upah dilakukan dengan pendekatan inflasi 5 tahunan 
3. PP Nomor 142 tentang Kawasan Industri yang menegaskan bahwa Kawasan industri merupakan infrastruktur yang sangat penting

4. Inpres Nomor 12 tahun 2015tentang Peningkatan Daya Saing Industri, Kemandirian Industri dan Kepastian Usaha

5. PP Nomor 2 tahun 2017 tentang Pembangunan Sarana dan Prasarana Industri

6. Perpres Nomor 91 tahun 2017 tentang Percepatan Pelaksanaan Berusaha

7. PP Nomor 29 tahun 2018 tentang Pemberdayaan Industri

8. Perpres Nomor 2 tahun 2018 tentang Kebijakan Industri Nasional 2015-2019, salah satu parameter yang mempengaruhi sasaran dari pembangunan industri yang meliputi stabilitas politik dan ekonomi untuk menunjang peningkatan pertumbuhan ekonomi nasional

Dari penjelasan regulasi di atas bahwa formulasi kebijakan mengacu pada industri nasional, yang menitikberatkan pada persoalan investasi besar, sehingga apabila tanpa adanya syarat infrastruktur yang jelas maka akan berdampak pada upah yang murah, dengan demikian berlakunya sebuah konstitusi bukanlah 
murni sekadar kaidah hukum melainkan hasil diskursus politik. Gerakan konstitualisme muncul berawal dari dinamika perkembangan masyarakat yang menuntut suatu perubahan khususnya dalam relasi tata negara agar sejalan dengan paham konstitusional tersebut. Konstitusi tidak sekadar dimaknai sebagai kaidah hukum secara tertulis tetapi tindakan yang diperlukan baik untuk pendekatan hukum maupun politik guna mendorong suatu perubahan tata kuasa sekaligus mampu membatasi kekuasaan agar tidak bertindak sewenangwenang. Oleh karena itu, konstitusi ini terus bergerak dinamis agar mampu mewujudkan kesejahteraan semua warga negara termasuk para buruh/pekerja.

\section{KONDISI BURUH TERHADAP TERBITNYA KEBIJAKAN OMNIBUS LAW UU NO. 11 TAHUN 2020 TENTANG CIPTA LAPANGAN KERJA DI INDONESIA}

Adanya RUU Omnibus dinilai mampu untuk memecahkan permasalahan yang ada seperti pengangguran yang tercatat sekitar 7 juta orang di Indonesia, setiap angkatan kerja baru yang bertambah 2 juta orang setiap tahunnya. Sementara itu jumlah pekerja informal mendominasi yaitu 74,1 juta pekerja (57,26\%) pada tahun 2019 dan pekerja formal sekitar 
55,3 juta $(42,74 \%)$. Di sisi lain untuk tetap menjaga pertumbuhan ekonomi nasional, maka pemerintah memerlukan investasi baru sebesar Rp 4.800 Triliun dan setiap 1\% memerlukan Rp 800 Triliun (sumber: cnbcindonesia.com). Untuk menjaga keseimbangan perluasan lapangan kerja dan pertumbuhan ekonomi nasional maka diperlukan reformasi regulasi secara menyeluruh termasuk untuk sektor ketenagakerjaan. Dengan kondisi seperti itu maka, omnibus law ini sebagai jawaban atau resolusi untuk perluasan lapangan kerja dan perlindungan pekerja sekaligus mengembalikan iklim investasi guna memperbaiki laju pertumbuhan ekonomi di negara Indonesia (Kementerian Perencanaan Pembangunan Nasional/ Badan Perencanaan Pembangunan Nasional, "Ringkasan Eksekutif Visi Indonesia 2045).

Dari perumusan kebijakan RUU Omnibus Law ini mencakup 1.244 pasal dari 79 yang kemudian disederhanakan menjadi payung hukum dan mampu menjawab permasalahan di sektor investasi maupun sektor tenaga kerja. Omnibus ini terbagi menjadi 11 kluster yakni (sumber: kompas.com) :

1. Penyederhanaan perizinan mencakup 52 Undang-Undang dari 770 pasal 
2. Persyaratan investasi mencakup 13 UndangUndang dari 24 pasal

3. Ketenagakerjaan mencakup 3 Undang-Undang dari 55 pasal

4. Kemudahan, pemberdayaan dan perlindungan UMKM mencakup 3 Undang-Undang dari 6 pasal

5. Kemudahan berusaha mencakup 9 UndangUndang dari 23 pasal

6. Dukungan riset \& Inovasi mencakup 2 UndangUndang dari 2 pasal

7. Administrasi pemerintahan ada 2 UndangUndang sebanyak 14 pasal

8. Pengenaan sanksi mencakup 49 Undang-Undang sebanyak 295 pasal

9. Pengadaan lahan mencakup 2 Undang-Undang sebanyak 11 pasal

10. Investasi dan proyek pemerintah mencakup 2 Undang-Undang sebanyak 3 pasal

11. Kawasan ekonomi mencakup 5 Undang-Undang sebanyak 38 pasal 
Adanya omnibus law ini ditujukan untuk menjawab permasalahan-permasalahan dalam UU sebelumnya yang mengatur tentang hak-hak bagi buruh. Akan tetapi omnibus law yang dibuat untuk memperbaiki kebijakan sebelumnya justru malah berbanding sebaliknya, adanya omnibus law ini malah memperkeruh keadaan serta mencederai beberapa aturan undang-undang sebelumnya banyak serikat buruh seperti SPSI yang menolak adanya perumusan kebijakan tersebut dikarenakan tujuan dari perumusan kebijakannya lebih berpihak pada kepentingan pengusaha atau investor daripada kepentingan buruh (Whardani, 2020). Adapun beberapa UU yang dianggap dilanggar oleh omnibus law antara lain UU No. 23 tahun 2014 tentang Pemerintah Daerah, PP No. 24 tahun 2018 Tentang Perizinan, UU No. 21 tahun 2000 tentaag Organisasi Serikat, Federasi, Konfederasi, UU No. 13 tahun 2003 tentang Ketenagakerjaan, Mengatur Jam Kerja dll, UU No. 2 tahun 2004 tentang Permasalahan Kerja dan Mengantisipasi Adanya PHK dan Juga Penetapan upah.

Beberapa pasalyang menjadi masalah pada omnibus law adalah pasal 89 ayat 25, pasal 156 undang-undang nomor 13 tahun 2003, pasal 156 ayat 1 nomor 13 tahun 2003 serta pasal 156 ayat 3 huruf g dan h , pasal pasal tersebut adalah pasal yang berfokus pada pemenuhan 
hak-hak buruh selama masa kerja dan pasal tersebut dihilangkan pada undang-undang cipta lapangan kerja, sehingga menimbulkan perselisihan serta kontra buruh dengan pemerintah (Kurniawan, \& Dewanto, 2020).

Para buruh menilai bahwa omnibus law Cipta Lapangan Kerja ini yang menindas dan tidak melibatkan serikat buruh seperti SPSI, SPN, GASBIINDO, KASBI dll. dalam perancang atau pembahasan RUU tersebut dan lebih mengagungkan posisi investor daripada memberikan perlindungan terhadap rakyatnya/buruh. Para ketua DPP dari serikat buruh ini juga menyatakan bahwa tidak akan menyerah serta mundur dalam keadaan apapun demi membela hak hak serta keadilan buruh serta akan terus memantau jalannya perumusan serta pengesahan omnibus law.

Anggapan tersebut tentu membuat para buruh semakin bersemangat dalam melakukan penolakan RUU Omnibus Law Cipta Lapangan Kerja, seperti peristiwa aksi demonstrasi yang dilakukan oleh para buruh di depan Gedung DPR pada senin (20 januari 2020) untuk menolak RUU Cipta Lapangan Kerja. Aksi demonstrasi tersebut tergabung dalam anggota Konfederensi Serikat Pekerja Indonesia (KSPI) dan afiliasi lainnya sekitar 25 ribu anggota, "ujar Sekjen FSPMI Riden Hatam Aziz di LBH Jakarta (18/1/2020). 
Selain itu, dalam aksi demonstrasi tersebut para buruh juga mengatakan akan mengadakan pemogokan massal di seluruh Indonesia apabila aspirasi mereka tidak di dengarkan oleh pemerintah. Dengan adanya aksi demonstrasi tersebut menunjukkan bahwa kontranya para buruh/pekerja terhadap RUU Omnibus Law Cipta Lapangan Kerja.

\section{KEBIJAKAN OMNIBUS LAW BAGI PEKERJA/ BURUH}

Kepastian hukum mengenai perundang-undangan maupun aturan yang ada di indonesia seringkali memberikan ketidakpastian dikarenakan undangundang yang tumpang tindih dan ketidakjelasan hukum dalam berbagai undang-undang, karenanya adanya RUU Omnibus Law ini dinilai sebagai resolusi dalam menyelesaikan permasalahan tersebut. Menurut Kurniawan (2020) dampak negatif yang harus diperhatikan adalah apabila RUU Cipta Lapangan Kerja tersebut disahkan oleh pemerintah maka nasib para buruh atau pekerja akan terdiskriminasi. Mirisnya apabila kebijakan RUU tersebut disahkan oleh pemerintah dan sangat berkontradiksi dengan kedudukan suatu kebijakan, dimana kebijakan diformulasikan untuk menjawab permasalahan yang 
terjadi di masyarakat bukan sebaliknya. Secara output dari RUU Omnibus Law ini sangat mengagungkan posisi investor / korporasi daripada memberikan perlindungan terhadap hak rakyatnya sendiri serta memberikan posisi kepada investor diatas segalanya (Kurniawan, \& Dewanto, 2020).

\section{PROBLEMATIKA OMNIBUS LAW}

Sampai saat ini tahapan dari omnibus law masih pada perumusan kebijakan atau formulasi dan belum sampai pada tahap implementasi. Permasalahan yang di maksud adalah ketika suatu kebijakan yang di formulasikan berpihak pada pemangku kepentingan tanpa melihat impact dari kebijakan itu. Hal ini menjadi tantangan tersendiri bagi pemerintah selaku perumus kebijakan untuk senantiasa mempertimbangkan kembali dalam memformulasikan kebijakan omnibus law sebenarnya ditujukan untuk apa, siapa dan bagaimana impact-nya. Adapun beberapa pasal pada omnibus law yang dianggap tidak relevan dengan UU maupun regulasi sebelumnya, dimana pada pasal-pasal tersebut yang menimbulkan adanya perdebatan masyarakat dalam menanggapi omnibus law ini terutama pekerja dan buruh. 
Disamping itu ketua umum SPSI LEM FSP mengatakan omnibus law dinilai banyak melibatkan pengusaha dan peran buruh hanya sebagai pendengar, dengan kata lain pemerintah tidak melibatkan serikat buruh dalam proses penyusunan RUU Cipta Lapangan Kerja. Padahal keterlibatan serikat buruh dalam proses penentuan pasal perlu dijadikan pertimbangan oleh Pemerintah, dikarenakan setiap kebijakan yang diambil tidak hanya mementingkan kepentingan pengusaha atas nama investasi, tetapi juga harus memperhatikan kepentingan buruh sebagai bentuk perlindungan, dengan demikian investasi dan juga perlindungan terhadap buruh bisa beriringan tanpa ada yang mendominasi (Kurniawan, \& Dewanto, 2020).

\section{PASAL-PASAL YANG MENJADI PERDEBATAN PARA BURUH}

Omnibus law cipta lapangan kerja memang menyimpan beberapa permasalahan di dalamnya seperti pasal-pasal terkait hak-hak buruh yang dihilangkan, yang mengakibatkan para buruh mengangkat beberapa isu yang dianggap hanya mementingkan kepentingan pragmatis pemerintah yang artinya menurut para buruh kebijakan yang semestinya dibuat untuk menyelesaikan permasalahan jutru malah sebaliknya, aturan yang 
dibuat ini menjadi mimpi buruk bagi kehidupan para buruh di Indonesia, pada tahun 2015 presiden Jokowi telah menetapkan PP No. 78 tentang upah akan tetapi PP tersebut di amandemen oleh omnibus law karena bertumpang tindih dengan undang-undang yang sebelumnya (Kurniawan \& Dewanto, 2020). Berikut ini adalah beberapa poin sudut pandang terhadap omnibus law cipta lapangan kerja.

Pertama, pengurangan upah minimum kerja adalah satu bentuk pertama terkait pengeksploitasian hak-hak buruh yang mana jika buruh tidak bekerja sesuai dengan peraturan jam kerja maka buruh tidak akan mendapatkan uang upah diatas nominal uang upah kerja, artinya aturan ini bertentangan dengan UndangUndang No. 13 tahun 2003 dan PP No. 78 tahun 2015 yang mengatur tentang upah serta jam kerja.

Kedua hilangnya peraturan tindak pidana bagi perusahaan yang melanggar hukum yang artinya perusahaan lebih leluasa dalam mengatur peraturan dan lebih semena-mena dalam melakukan pelanggaran yang ada serta dengan mudah menghilangkan kewajibannya dalam memenuhi hak-hak buruh karena tidak adanya payung hukum atau regulasi yang mengatur perusahaan tersebut, ini adalah mimpi buruk bagi para buruh yang terus terusan akan merasa dieksploitasi oleh perusahaan. 
Ketiga hilangnya cuti bagi para buruh perempuan haid atau hamil yang artinya hilangnya pemenuhan kebutuhan primer buruh perempuan yang harus terus menerus dipaksa untuk bekerja agar tidak adanya pemotongan upah kerja yang membahayakan kesehatan para buruh perempuan,

Keempat jika kita berkaca pada UU No. 2 tahun 2004 tentang Permasalahan Kerja Dan Mengantisipasi Adanya PHK Dan Juga Penetapan UPAH, mengacu pada persoalan PHK atau pemutusan hubungan kerja yang dilakukan oleh pihak perusahan dengan pekerja atau buruh, dalam UU tersbeut dikatakan bahwa PHK sebisa mungkin diminimalisir atau bahkan diantisipasi agar tidak terjadi. Hal tersebut mengingat bahwasanya pekerja dan buruh secara penuh menggantungkan hidupnya pada perusahaan, jika seorang pekerja dan buruh mengalami PHK otomatis ini akan menimbulkan dampak yang kompleks khususnya ekonomi. Dengan demikian UU tersebut seolah-olah tidak mengindahkan adanya sebuah PHK yang dilakukan terhadap pekerja atau buruh.

Akan tetapi perlu kita ketahui bahwa dalam kebijakan omnibus law justru diduga semakin memudahkan perusahaan dalam melakukan PHK terhadap karyawannya. Hal ini dibuktikan dalam omnibus law 
yang belum pasti kapan di sahkan dijelaskan jika PHK masuk dalam asuransi BPJS dengan maksud agar nantinya jika terjadi PHK yang mungkin tidak diinginkan karena permasalahan dari perusahaan, setidaknya pekerja dan buruh telah memiliki jaminan untuk hal itu. Namun yang perlu digaris bawahi adalah seperti yang kita ketahui bahwa asuransi BPJS itu dikenakan tarif setiap bulan yang dibebankan pada penggunanya sesuai dengan kelas yang dipilih. Karenanya disini dapat dikatakan bahwa pekerja atau buruh membayar biaya asuransi untuk PHK dirinya sendiri (Achmad Nurcholis, 2019).

Dengan begini penolakan omnibus law adalah jalan satu satunya yang harus di ambil oleh para buruh dan pekerja demi mengamankan hak-haknya, sebab jika tidak melakukan penolakan maka para buruh akan terus tereksploitasi oleh aturan-aturan yang dibuat oleh perusahaan dan perushaan akan lebih mudah untuk memainkan roda industrial dikarenakan tidak adanya aturan yang mengatur pelanggaran yang telah dilakukan oleh perusahaan terhadap buruh (Marcella, \& Sudibya, 2020).

\section{DAMPAK YANG DIRASAKAN OLEH BURUH APABILA DISAHKAN RUU CILAKA}


Dalam setiap pembentukan kebijakan pasti akan melahirkan dampak atau pengaruh bagi seluruh rakyat Indonesia baik itu pengaruh baik atau positif maupun buruk atau negatif. Pengaruh-pengaruh itulah yang kemudian menimbulkan reaksi publik menjadi target kebijakan tersebut. Respon dari publik disesuaikan dengan dampak yang ditimbulkan oleh kebijakan tersebut, artinya jika kebijakan berdampak positif maka mereka juga akan pro terhadap kebijakan. Sebaliknya jika kebijakan yang nantinya akan hanya membawa pengaruh negatif maka masyarakat juga melakukan penolakan.

Seperti halnya rencana penerapan kebijakan omnibus law yang sampai saat ini masih pada tahap formulasi atau perumusan dikarenakan beberapa kendala tertentu, tetapi sejak awal pembentukan hingga perumusan nampaknya omnibus law UU No. 11 Tahun 2020 tentang Cipta Lapangan Kerja mengalami pertentangan dari masyarakat Indonesia terutama buruh dan pekerja.

Omnibus Law UU No. 11 Tahun 2020 tentang Cipta Kerja merupakan salah satu kebijakan yang ada di dalam omnibus law dengan tujuan meningkatkan atau mencitakan lapangan kerja, namun Rencana pemerintah melakukan deregulasi melalui RUU Cilaka 
ini mendapat penolakan dari kalangan buruh dengan alasan RUU Cilaka memiliki potensi dalam menurunkan kesejahteraan bagi buruh/pekerja. Secara umum omnibus law memang membawa pengaruh atau dampak positif untuk memperkuat jaringan ivestasi dengan para investor, sehingga dapat meningkatkan daya saing ekonomi Indonesia khususnya ekonomi secara global.

Tetapi, disisi lain dampak posiitif omnibus law juga membawa dampak negatif terutama bagi buruh karena dapat merugikan terutama pada pekerja perempuan yang nantinya peran perempuan akan semakin terdeskriminasi. Berikut adalah dampak negatif dari omnibus law secara umum antara lain (Kurniawan, \& Dewanto, (2020).

1. Melegitimasi investasi perusak lingkungan, mengabaikan investasi rakyat dan masyarakat adat yang lebih ramah lingkungan dan mensejahterakan

Kolaborasi investor dengan pemerintah Indonesia nyatanyabelum mampu meningkatkan pertumbuhan ekonomi serta perdagangan dikarenakan ketidak selektifan pemerintah dalam membuka ruang terhadap investor asing. Dalam artian ivestor yang telah diberikan 
ruang oleh pemerintah belum mampu untuk menjawab permasalahan permasalahan yang di hadapi, salah satunya permasalahan terkait buruh yang mana banyak para investor asing ini yang mengeksploitasi para buruh atau tenaga kerja Indonesia, serta banyak juga para investor asing yang memanfaatkan hubungan bilateral untuk memperluas pengeksplotasian alam serta merusak alam yang ada di Indonesia. Tetapi pemerintah masih saja memepertahankan para investor asing dan melupakan masyarakat lokal atau investor lokal yang juga dapat membantu meningkatkan pertumbuhan perekonomian di Indonesia serta membuka lapangan pekerja (Gultom, \& Reresi, 2020). 


\section{Celah korupsi melebar akibat mekanisme} pengawasan yang dipersempit dan penghilangan hak gugat oleh rakyat

Mebuka celah yang di maksud adalah bagaimana omnibus law cipta lapangan kerja ini hanya condong pada satu sisi yaitu investor yang mana syarat akan perizinan sudah terbuka lebar meskipun itu berdampak pada lingkungan hidup. Dengan mudahnya perizinan ini maka membuat para investor lebih mudah untuk memainkan money politic bersama pemerintah dalam pembukaan lahan ilegal yang seharusnya menjadi ekosistem satwa, dan juga dengan ini masyarakat sudah tidak bisa lagi ikut andil dalam pengawasan tahap pemformulasian kebijakan karena terbatasnya akses serta tertutupnya informasi pemerintah kepada masyarakat, yang membuat para koruptor semakin leluasa dalam melancarkan aksinya (Gultom, \& Reresi, 2020).

\section{KESIMPULAN}

Dari semua penjelasan yang telah dipaparkan terkait dengan omnibus law bahwa keberhasilan suatu kebijakan dapat dilihat dari sejauh mana kebijakan 
tersebut mampu menjawab permasalahan yang ada di kehidupan masyarakat baik itu dalam aspek ekonomi, sosial, politik maupun aspek lainnya. Hal ini menjadi tantangan tersendiri bagi pemerintah selaku perumus kebijakan untuk senantiasa mempertimbangkan kembali dalam memformulasikan kebijakan omnibus law sebenarnya ditujukan untuk apa, siapa dan bagaimana impact-nya.

Adapun beberapa pasal pada omnibus law yang dianggap tidak relevan dengan UU maupun regulasi sebelumnya, dimana pasal-pasal tersebut ada yang menimbulkan perdebatan masyarakat dalam menanggapi omnibus law ini terutama pekerja dan buruh. Disamping itu omnibus law dinilai banyak melibatkan pengusaha dan peran buruh hanya sebagai pendengar, dengan kata lain pemerintah tidak melibatkan serikat buruh dalam proses penyusunan RUU Cipta Lapangan Kerja. Maka dari itu hingga saat ini masih menjadi polemik yang belum ada kejelasan terkait omnibus law ini apalagi indonesia saat ini masih terkena pandemik Covid 19.

Harapannya kedepan pemerintah dalam memformulasikan kebijakan mampu menjawab berbagai permasalahan di masyarakat, terutama bagi kaum buruh, seperti yang sudah dipaparkan sebelumnya bahwa masih banyak poin-poin yang menjadi permasalahan dan 
membuat celah bagi para investor untuk melangsungkan kegiatan KKN maupun memeras para buruh ataupun pegawai pabrik dengan dalih pemberian asurasi ataupun sebagainya. Kejadian ini merupakan tamparan keras untuk pemerintah sebagai pemangku serta pembuat kebijakan agar lebih waspada dan mengerti kebutuhan, seperti apa yang di butuhkan oleh masyarakat yang sebenarnya, tidak hanya mementingkan kepentingan sepihak. Karena sejatinya kesejahteraan masyarakat dapat dikatakan berhasil apabila pemerintah dan masyarakat mampu berkolaborasi membangun suatu negara yang adil dan lebih mementingkan kepentingan rakyat bukan kepentingan individu. 


\section{REFERENSI}

Bintari, A., \& Pandiangan, L. H. S. (2016). Formulasi Kebijakan Pemerintah tentang Pembentukan Badan Usaha Milik Daerah (BUMD) Perseroan Terbatas (PT) Mass Rapid Transit (MRT) Jakarta di Provinsi DKI Jakarta. CosmoGov: Jurnal Ilmu Pemerintahan, 2(2), 220-238. Vol.2, No.2, 220-238.

Dunn, William N. 2000. Analisis Kebijakan Publik. Edisi Kedua. Yogyakarta: Terjemahan Samodra Wibawa dkk. Gajah Mada University Press.

Fitryantica, A. (2019). Harmonisasi Peraturan PerundangUndangan Indonesia melalui Konsep Omnibus Law. Gema Keadilan, 6(3), 300-316.

Gultom, A. F., \& Reresi, M. (2020). Kritik Warga Pada Ruu Omnibus Law Dalam Paradigma Critical Legal Studies. Jurnal Pendidikan Kewarganegaraan, 1O(1), $38-47$.

Hamdi, M. (2014). Kebijakan publik: proses, analisis, dan partisipasi. Ghalia Indonesia.

Hadari Nawawi.(1983). Metode Penelitian Bidang Sosial. Pontianak: Gadjah Mada university press.

http://majalahsedane.org/omnibus-law-dan-politikhukum-perburuhan/ 
Juwana, S., Gianova, G., \& Mega, G. (2020). Sistem dan Praktik Omnibus Law di Berbagai Negara dan Analisis RUU Cipta Kerja dari Perspektif Good Legislation Making. Policy Brief

Kementerian Perencanaan Pembangunan Nasional/Badan

Perencanaan Pembangunan Nasional, "Ringkasan Eksekutif Visi Indonesia 2045," (Oktober 2018)

Kurniawan, F., \& Dewanto, W. A. (2020). Problematika Pembentukan RUU Cipta Kerja Dengan Konsep Omnibus Law Pada Klaster Ketenagakerjaan Pasal 89 Angka 45 Tentang Pemberian Pesangon Kepada Pekerja Yang Di PHK. Jurnal Panorama Hukum, 5(1), 63-76.

Marcella, Y., \& Sudibya, K. P. Peran Organisasi Serikat Pekerja/Buruh Dalam Pembangunan Perekonomian Indonesia. Kertha Semaya: Journal Ilmu Hukum, 4, $1-15$.

Lorne Gunther, "Omnibus bills in Hill History," https:// torontosun.com/2012/o6/18/omnibus-bills-inhillhistory/wcm/5b85232b-b 8b4-4c9b-b5b79480b9821292, diakses pada 7 Juli 2020.

Lexy, J. M. (2006). Metode Penelitian Kualitatif Edisi Revisi. Bandung: Remaja Rosdakarya. 
Lindblom, Charles E. (1980). Proses Penetapan Kebijakan(terjemahan). Jakarta: Erlangga.

Miles, M. B. D. A. (1992). Michael Huberman. 1992. Analisis Data Kualitatif.

Ramdhani, A., \& Ramdhani, M. A. (2017). Konsep umum pelaksanaan kebijakan publik. Jurnal Publik, 11(1), 1-12.

repo.iain-tulungagung.ac.id>PDF BAB II KAJIAN PUSTAKA

A. Buruh 1. Pengertian Buruh Pada zaman feudal.

Robbins, P. Stephen (2003), "Organizational Behavior : Concept, Controversies”, Application. Seventh Edition. Prentice Hall Inc.

Saputra, R., \& Retnowati, T. (2021). KAJIAN YURIDIS TERHADAP GAJI PEKERJA DIBAWAH UPAH MINIMUM KOTA PADA USAHA YANG TIDAK BERBADAN HUKUM. NUSANTARA: Jurnal Ilmu Pengetahuan Sosial, 8(3), 118-124.

https://www.google.com/amp/s/amp.kompas.com/ nasional/read/2020/02/12/07454901/jika-omnibuslaw-cipta-lapangan-kerja-disahkan-buruh-siap-ujidi-mk (Diakses pada 24 April 2020, pukul 16.10 WIB).

h t t p s : / / n a sio n a l. kom pa s. com / $\mathrm{read} / 2020 / 02 / 12 / 11173351 /$ surpres-dan-drafomnibus-law-cipta-lapangan-kerja-dikirim-ke-dpr (Diakses pada 24 April 2020, pukul 16.20 WIB). 
h t t p s : / / n a s i o n a l. k o m p a s. c o m / $\mathrm{read} / 2020 / 01 / 31 / 08554991 /$ ketidakpuasanjokowi-atas-draf-omnibus-law-ruu-cipta-lapangankerja?page $=3$ (Diakses pada 25 April 2020, pukul 10.12 WIB).

h t t p s : / / n a s i o n a l. k o m p a s. co m / $\mathrm{read} / 2020 / 02 / 11 / 19180051 / \mathrm{rabu}$-puluhan-ribuburuh-kepung-gedung-dpr-untuk-protes-omnibuslaw (Diakses pada 22 April 2020, pukul 20.38 WIB).

h t t p s : / / n a s i o n a l. k o m p a s. co m / $\mathrm{read} / 2020 / 02 / 11 / 20563471 / d p r-s u d a h-t e r i m a-d r a f-$ omnibus-law-perpajakan (Diakses pada 24 April 2020, pukul 14.20 WIB).

https://www.cnbcindonesia.com/news/202001210908374-131452/apa-sih-omnibus-law-cilaka-yang-bikinburuh-marah/2 (Diakses pada 22 April 2020, pukul 20.39 WIB).

h t t p s : / / a m p . k o m p a s . c o m / m o n e y / $\mathrm{read} / 2020 / 01 / 20 / 080941626 /$ hari-ini-buruh-demotolak-omnibus-law-cipta-lapangan-kerja-apa-sajaisi-ruu (Diakses pada 23 April 2020, pukul 10.30 WIB). 
https://www.hukumonline.com/berita/baca / lt5e14697a698ff/kalangan-buruh-sebut-enamdampak-buruk-omnibus-law-bagi-buruh/ (Diakses pada 24 April 2020, pukul 18.10 WIB).

http://majalahsedane.org/omnibus-law-dan-politikhukum-perburuhan/ (Diakses pada 23 April 2020, pukul 10.10 WIB).

igj.or.id > uploads > 2020/01PDF 12 Alasan Menolak Omnibus Law RUU Cilaka (\#Cilaka12) (Diakses pada 23 April 2020, pukul 15.00 WIB). 